\title{
Obchody dwudziestolecia III Rzeczypospolitej. Próby kształtowania pamięci zbiorowej polskiego społeczeństwa
}

D wadzieścia lat po narodzinach III Rzeczypospolitej nic co dotyczyło jej narodzin nie było już oczywistym. Nawet sam termin III RP, który jeszcze na początku lat dziewięćdziesiątych zdawał się być symbolem nowego otwarcia w naszych dziejach, synonimem zwycięstwa i zerwania z niedawną przeszłością, zaczął kojarzyć się wielu Polakom z zaniechaniem, kunktatorstwem, patologia, a nawet zdradą. Z takich nastrojów wzięła się przecież retoryczna i polityczna siła hasła „IV RP”, jakże nośna u schyłku dwudziestolecia 1989-2009. W głęboko podzielonym polskim społeczeństwie, wobec którego co bardziej krewcy politycy i publicyści nie wahają się używać terminu „dwie Polski”, zapożyczonego z czasów poprzedzających wojnę domową w Hiszpanii, jednym z czynników podziału stały się kwestie historyczne, a w zasadzie wyznawana wizja przeszłości w odniesieniu do kilku węzłowych faktów i zjawisk. Zaistniała wyraźna korelacja pomiędzy aktualnymi zapatrywaniami politycznymi a oceną takich wydarzeń sprzed lat dwudziestu, jak: kontrakt okragłego stołu, wybór gen. Jaruzelskiego na prezydenta czy kształt i działania rządu Tadeusza Mazowieckiego. Narodziła się wręcz, jak pisał A. Hall, czarna $i$ złota legenda początków III Rzeczpospolitej. Która z nich zwycięży w sferze zbiorowej pamięci społeczeństwa, zyska dominację w obszarze społecznych wyobrażeń przeszłości? Odpowiedź na tak postawione pytanie stała się istotnym elementem diagnozy stanu współczesnej sceny publicznej. Mówiąc wprost: zaszczepienie w umysłach Polaków własnej interpretacji mitu założycielskiego III RP mogło wpłynąć na ukształtowanie się ich politycznych sympatii i decyzje przy urnach wyborczych. Walka o pamięć stała się w istocie walką o władzę, nie tylko w sferze symbolicznej. Trudno się wobec tego zgodzić z tezą Dariusza Gawina, postawioną przy okazji podsumowania obchodów dwudziestolecia III RP, oznajmiającą: nowy konsensus dotyczacy pamięci demokratycznej wspólnoty politycznej Polaków zrodzony jakoby wokół: neo-solidarnościowej wersji pamięci aksjologicznej ${ }^{1}$. Gdzież bowiem znajduje się ów solidarnościowy wzorzec pamięci, skoro ani dzisiejsze, ani tym bardziej dawne wcielenie Związku nie wypracowało żadnej w tej kwestii jedności, a wszystkie strony sporu legitymizują swoje wersje przeszłości odwoływaniem się do różnych elementów tradycji solidarnościowej.

Dlatego warto podjąć politologiczną refleksję nad współczesnymi sposobami upamiętniania wydarzeń roku 1989 i umieścić ją w kontekście badań nad pamięcią w wymiarze społecz-

1 D. Gawin, Polityka historyczna. Próba bilansu, „Arcana” 2009, nr 90, s. 30-31. 
nym. Obchody dwudziestolecia istnienia III RP, które zbiegły się w czasie z okragłą rocznicą roku 1939, zamykającego dzieje poprzedniej formy naszej państwowości - II RP, były organizowane na wielu obszarach i przybierały różne formy. Nie we wszystkich objawiał się intencjonalny zamiar kształtowania zbiorowej pamięci społeczeństwa, nie zawsze towarzyszyła im atmosfera ,walki o pamięć”. Mniej była ona widoczna w ramach podejmowanych projektów badawczych i organizowanych konferencji naukowych, bardziej przy okazji oficjalnych uroczystości firmowanych przez instytucje państwa, szczególnie zaś wyraźnie dostrzec ją możemy w publicystycznych debatach goszczących na forach politycznie zaangażowanych mediów. Te właśnie, wymienione powyżej, „obszary upamiętniania” są przedmiotem refleksji w ramach niniejszego tekstu, którego ambicją jest również dostrzeżenie w nich „obszarów polityki pamięci” prowadzonej przez rozmaite instytucje i środowiska.

Poruszać będziemy się w kręgu terminów i znaczeń wielce niejednoznacznych i wciąż szeroko dyskutowanych, warto byłoby zatem dokonać kilku terminologicznych uściśleń, które pomóc winny zakreśleniu, niezbędnego dla omawianych form upamiętniania, kontekstu.

Kluczowe dla poniższych rozważań są niewątpliwie dwa pojęcia: „pamięć zbiorowa” i ,polityka pamięci”. Pierwsze z nich ma długą tradycję stosowania i sięga klasycznych już dziś ustaleń Maurice`a Halbwachsa ${ }^{2}$. Od niego rozpoczyna swoje istnienie nurt badań nad pamięcią i zapominaniem, którego najbardziej znaczącymi przedstawicielami zdają się: Paul Ricoeur, Pierre Nora, czy Jan i Aleida Assmannowie. W Polsce posiadamy długą tradycję naukowej refleksji nad tymi zagadnieniami. Zaczęli ją prowadzić, jeszcze w latach sześćdziesiątych Nina Assorodobraj i Stefan Czarnowski, obecnie zaś najważniejsze teksty wychodzą spod pióra Barbary Szackiej, Andrzeja Szpocińskiego, Lecha M. Nijakowskiego, czy Aleksandry Jasińskiej Kani ${ }^{3}$. Ważną częścią owej refleksji jest dokonanie rozróżnień między pojęciami pamięci historycznej, pamięci społecznej i pamięci zbiorowej oraz odniesienie ich do odpowiednich sfer świadomości społecznej, stworzenie zatem wyrazistej siatki pojęć, które ułatwiłyby naukową kategoryzację tak ulotnej, jak pamięć jednostek i społeczeństw, sfery. Nie ma w tym tekście oczywiście potrzeby i miejsca szerokiego zdawania sprawy z tych działań, należy jednak przyjąć konkretną definicję pamięci zbiorowej, pamiętając jednak, iż jest to zabieg dość woluntarystyczny. Najbardziej użyteczna zdaje się tu definicja B. Szackej, która ukazuje pamięć zbiorową jako: zbiór wyobrażeń członków zbiorowości ojej przeszłości, o zaludniajacych ja postaciach i minionych wydarzeniach jakie w niej zaszły, a także sposobów ich upamiętniania i przekazywania o nich wiedzy uważanej za obowiazkowe wyposażenie członka tej zbiorowości ${ }^{4}$. Akceptując tą tezę warto przytoczyć spostrzeżenie A. Szpocińskiego, który sugeruje, iż po roku 1989 elity artystyczne i intelektualne tracą tą rolę na rzecz elit politycznych i mediów. Kanałami najefektywniejszego oddziaływania na postawy społeczne wobec przeszłości zaczynają być najpopularniejsze środki społecznego przekazu ${ }^{5}$.

Tak rozumiana pamięć zbiorowa spełnia w społeczeństwie wiele istotnych funkcji. Najważniejsze, z punktu widzenia naszych rozważań, są niewątpliwie: funkcja tożsamościowa i funkcja legitymizacyjna ${ }^{6}$. Pierwsza, nazywana również niekiedy integracyjną, służy utwierdzaniu jednostek w przekonaniu, iż są częścią istniejącej od dawna zbiorowości. Wzmacnia

\footnotetext{
${ }^{2}$ M. Halbwachs, Społeczne ramy pamięci, Warszawa 1969.

${ }^{3}$ Szeroko problem historii i stanu badań nad pamięcią zbiorową zawiera najnowsza książka B. Szackiej, Czas przeszly, pamięć, mit, Warszawa 2006, s. 32-45.

4 Ibidem, s. 19.

${ }^{5}$ A. Szpociński, P. T. Kwiatkowski, Przeszłość jako przedmiot przekazu, Warszawa 2006, s. 30 i n.

${ }^{6}$ B. Szacka, op. cit., s. 52-56.
} 
tożsamość grupową poprzez świadome wspieranie takiego obrazu przeszłości, który budzi emocjonalny oddźwięk wśród członków owej zbiorowości. Konstruowany i wzmacniany jest poprzez to wspólny dla nich system wartości i wzorców zachowania. Funkcja legitymizacyjna dotyczy uprawomocniania istniejącego porządku społeczno-politycznego, czyli struktur społecznej dominacji i form władzy politycznej. Dominacja w społeczeństwie, którejś z form zbiorowej pamięci jest więc istotną wartością zarówno dla państwa i jego aktualnych władz, jak również dla różnych środowisk i instytucji aspirujących do uzyskania wpływu na życie publiczne. Dla uzyskania panowania w sferze społecznych wyobrażeń przeszłości prowadzą one działania, które możemy nazwać „polityką historyczną” lub „polityką pamięci”.

Autor współczesnej monografii dotyczącej owej problematyki: L. M. Nijakowski, preferuje tu sformułowanie ,polityka pamięci”, nie dokonując jednakże wyraźnej dystynkcji oddzielającej je od „polityki historycznej””. Brak jasnej definicji pozwala tu na pewną dowolność, pragnęlibyśmy jednak opowiedzieć się za stosowaniem terminu „polityka pamięci” właśnie na gruncie refleksji naukowej, jako że „polityka historyczna” zbyt często pojawia się w polemikach natury politycznej. Trudno pisać o niej bez zagrożenia bycia zaklasyfikowanym jako zwolennik tej lub innej opcji politycznej ${ }^{8}$. „Polityka pamięci” w najwęższym rozumieniu jest przez Nijakowskiego definiowana jako: wszelkie intencjonalne działania polityków i urzędników, majace formalna legitymizację, których celem jest utrwalenie, usunięcie lub redefinicja określonych treści pamięci zbiorowej. ${ }^{9}$. Autor sugeruje, iż w tym znaczeniu pozostaje ona bliska propagandzie państwowej. Można by, w ramach naszych rozważań, zaproponować pewne rozszerzenie takiego rozumienia o media, szczególnie prasę, która nie wypełnia w sporze o przeszłość wyłącznie funkcji informacyjnej, ale dąży do zasugerowania określonej wizji historii.

Okolicznościowa refleksja, która dotyczy sfery nauki i wyraża się przy okazji spotkań naukowych, projektów i publikacji, również może być postrzegana w odniesieniu do pojęć pamięci zbiorowej i polityki pamięci, choć odniesienia te przybierają tu formę dyskretniejsza, bardziej subtelną niż w ramach form upamiętniania obecnych w mediach i podczas imprez organizowanych przez władze oraz rozmaite instytucje i środowiska. Poziom emocji towarzyszących ocenie zdarzeń sprzed lat dwudziestu dawał jednak o sobie znać również w tekstach o ambicjach naukowych, co da się zauważyć w wielu okolicznościowych publikacjach. I tam bowiem odnaleźć możemy słabo kamuflowaną apologię PRL i jej dziedzictwa, albo propagandę idei IV Rzeczypospolitej, choć, rzecz jasna, refleksja naukowa w najniższym stopniu nadaje się do interpretacji w ramach pojęcia „polityki pamięci”. Przejdźmy zatem do przeglądu tych spotkań o charakterze naukowym, które dotyczyły początków III Rzeczypospolitej.

Konferencje dotyczące roku 1989 rozpoczęły się na początku lutego, a więc w rocznicę rozpoczęcia obrad okraggłego stołu. Pierwsza z nich odbyła się 5 lutego w sali kolumnowej Sejmu z udziałem m.in.: Wojciecha Jaruzelskiego Tadeusza Mazowieckiego, Adama Michnika i Aleksandera Kwaśniewskiego oraz Władysława Frasyniuka, Henryka Wujca, Andrzeja Celińskiego, a także ekspertów i historyków (Janusz Reykowski, Henryk Samsonowicz, Andrzej Garlicki). Dyskusja podzielona była na kilka paneli. Rozmawiano o filozofii Okragłego

\footnotetext{
${ }^{7}$ L. M. Nijakowski, Polska polityka pamięci. Esej socjologiczny, Warszawa 2008, s. 41-48.

${ }^{8}$ Niestety na pewien przerost politycznego zaangażowania zdaje się w niektórych partiach cierpieć wspomniana powyżej praca L. M. Nijakowskiego.

${ }^{9}$ Ibidem, s. 44.
} 
Stołu, mechanizmie osiagania porozumienia w warunkach głębokiego konfliktu i praktyce budowy demokracji w Polsce po 1989 roku $^{10}$.

Następnego dnia z inicjatywy prezydenta Lecha Kaczyńskiego odbyła się druga konferencja na temat okragłego stołu. Wprowadzenie do dyskusji wygłosili dwaj historycy: prof. Wojciech Roszkowski oraz prof. Andrzej Paczkowski. Przybycie na konferencję zapowiedzieli też, m.in. Andrzej Ajnenkiel, Piotr Szarota, Andrzej Friszke i Piotr Gontarczyk. Szef Kancelarii Prezydenta Piotr Kownacki powiedział wyraźnie w wywiadzie dla TVP Info, że konferencja u prezydenta jest organizowana $w$ kontrze do spotkania $w$ Sejmie ${ }^{11}$.

Były to więc konferencje właściwie mocno polityczne, z wyraźnym obliczem ideowym, z udziałem naukowców (głównie historyków), ale stanowili oni jedynie tło dla wystąpień politycznych.

Podobnie będzie w czerwcu 2009 roku. Trudno bowiem nie określić jako czytelnej politycznie konferencji zatytułowanej: „Pomiędzy PRL a III RP - 20 lat transformacji”, która odbyła się w Sejmie 4 czerwca 2009 roku w rocznicę wyborów. Zorganizowana przez Fundację „Veritas et Scientia” oraz skupione wokół Fundacji środowiska niepodległościowe. Wśród zaproszonych gości i prelegentów byli: Jan Olszewski, Antoni Maciarewicz, J. Kropiwnicki oraz Wojciech Roszkowski i Andrzej Zybertowicz ${ }^{12}$.

I podobnie jak w lutym była i druga konferencja dzień później 5 czerwca w Auli Starej Biblioteki Uniwersytetu Warszawskiego: „Polski rok 1989”. Wzięli w niej udział min. premier Tadeusz Mazowiecki, prezydenci Aleksander Kwaśniewski i Lech Wałęsa oraz minister pracy w rządzie Helmuta Kohla, Norbert Blüm. Pierwszy panel - „Polski rok 1989 - wielkie wydarzenia i godna ich interpretacja" - moderował prof. Piotr Węgleński, były rektor UW, a panelistami byli Tadeusz Mazowiecki i Aleksander Kwaśniewski. Uzupełnieniem było odrębne spotkanie $\mathrm{z}$ Lechem Wałęsą ${ }^{13}$.

Dodajmy, bo to ciekawe, obydwie konferencje nazywały się naukowymi.

Trzecia największa odbyła się w Gdańsku w dniach 3-4 czerwca zorganizowana przez Europejskie Centrum Solidarności. Spotkanie z jednej strony miało być spojrzeniem w przeszłość i dlatego w pierwszej jej części spotkać się mieli politycy uczestniczący w procesie przeobrażeń politycznych roku 1989. Organizatorzy oczekiwali również że konferencja będzie próbą naukowej analizy historyków i politologów i konsekwencji, jakie przyniosły zmiany roku 1989 Polsce, Europie i światu. Udział w niej potwierdzili Vytautas Landsbergis - były prezydent Litwy, Żeliu Żelew - były prezydent Bułgarii, Vaclav Havel - były prezydent Czech, Hans Dietrich Genscher - były minister spraw zagranicznych Niemiec, Douglas Richard Hurd - były minister spraw wewnętrznych i były minister spraw zagranicznych Wielkiej Brytanii, Ján Čarnogurský - były premier Słowacji oraz naukowcy a wśród nich m.in.: Andrzej Paczkowski, Jadwiga Staniszkis, Antoni Dudek, Edmund Wnuk-Lipinski ${ }^{14}$.

\footnotetext{
${ }^{10}$ A. Leszczyński, Kto wygrat przy okragłym stole?, „Gazeta Wyborcza” 5.02.2009, http://wyborcza.pl/ 1,76842,6239824,Kto_wygral_przy_Okraglym_Stole_.html. Por.: „Wprost” 5.02.2009, http://www.wprost.pl/ar/ 152567/Konferencja-OKragly-Stol-to-fenomen-w-skali-swiatowej/.

${ }^{11}$ Instytut Pamięci Narodowej, http://www.ipn.gov.pl/portal/p1/18/8879/PRZEGLAD_MEDIOW_5_lutego_2009.html.

${ }^{12}$ Fundacja „Veritas et Scientia”, http://www.vetsc.org/start/index.php?option=com_content\&view=article\&id= 8:sprawozdanie-z-konferencji-qpomidzy-prl-a-iii-rp-20-lat-transformacjiq\&catid=1:aktualnoci.

${ }^{13}$ Portal Moje opinie.pl, http://www.mojeopinie.pl/miedzynarodowa_konferencja_naukowa_polski_rok_1989, 3,1244492574 .

${ }^{14}$ Europejskie Centrum Solidarności, http://www.ecs.gda.pl/newss/news/1157.
} 
Dużo mniejszy rozgłos medialny miały konferencje organizowane przez poszczególne ośrodki naukowe. Jeszcze wiosną tego roku w dniach 7-8 maja 2009 r. odbyła się zorganizowana z dużym rozmachem konferencja pod tytułem: „Od Okragłego Stołu do III RP”. Organizatorzy: Instytut Historii UJ, Koło Naukowe Historyków Studentów UJ, stawiali sobie następujące pytania: Jak widzieć rok 1989? Jako zakończenie procesu ewolucji systemu czy zdradę ideałów solidarnościowych? Czy były inne wizje rewolucji? Czy można było kontestować system i opozycję równocześnie, czy trzeba było dokonywać ważkich wyborów pod wpływem ruchów masowych czy też indywidualnie? Referaty wygłosili i udział w dyskusjach panelowych wzięli m.in.: Janusz Kurtyka, Antoni Dudek (Obóz władzy 1989), Andrzej Leon Sowa, Andrzej Zybertowicz (Strukturalny konflikt interesów jako fundament III RP), Sławomir Cenckiewicz (Udziat SB w transformacji 1988-1989), Jakub Polit, Andrzej Chwalba, Jan Rydel, Lubomir Zyblikiewicz. Panele dyskusyjne poświęcono wydarzeniom 1989 roku: Dwie wizje rewolucji? - czy spór o pryncypia? Obraz przełomu 88/89 w oczach uczestników oraz: Czy Okragły Stót byt jedyna droga od PRL do III RP $P^{15}$.

Instytut Historii i Stosunków Międzynarodowych Uniwersytetu Szczecińskiego był organizatorem sesji pt.: „Oblicza polskiej modernizacji. Bilans transformacji systemowej III RP”. Odbyła się ona 16 maja 2009 roku i warto podkreślić, że całość obrad sesji plenarnej dotyczyła wydarzeń roku 1989 (m.in.: Jerzy Eisler - Dziedzictwo Peerelu, Adam Leszczyński - Punkt startu. Czy w 1989 r. społeczeństwo polskie byto społeczeństwem nowoczesnym?, Ryszard Sielezin - Okragły Stót: element gry politycznej czy poczatek procesu modernizacji Polski. Próba oceny, Eugeniusz Ponczek - Przełom systemowy roku 1989 w Polsce: od transformacji do modernizacji). Obrady w sekcjach dotyczyły problematyki ekonomicznej, regionalno-samorządowej zagranicznej i transformacji ustrojowej ${ }^{16}$.

Jesienne sesje zacząć trzeba od „I Ogólnopolskiego Kongresu Politologii”, który odbył się w Warszawie w dniach 22-24 września. Odbyła się tam dyskusja nad projektem przygotowanym przez Marka Jabłonowskiego pt.: „Polski rok 1989. Sukcesy, zaniechania, porażki”. Udział w niej wzięli Paweł Machcewicz, Daria Nałęcz i Arkadiusz Żukowski ${ }^{17}$.

Warto zwrócić uwagę, że mijające dwudziestolecie nowej rzeczywistości sprzyjało porównaniom z okresem dwudziestolecia międzywojennego, którego okrąłą rocznicę upadku też obchodziliśmy w 2009 roku. Odbyły się, więc jeszcze jesienią dwie duże konferencje dotyczące owych właśnie porównań, gdzie siłą rzeczy część wystąpień w większym lub mniejszym stopniu dotyczyła genezy i znaczenia roku 1989. Pierwsza chronologicznie konferencja („Dwudziestolecia. Bilans sukcesów i niepowodzeń państwowości polskiej w okresie międzywojennym i w latach 1989-2009”) zorganizowana została w dniach 20-21 października przez Zakład Historii Najnowszej 1918-1945, Zakład Metodologii i Dydaktyki Historii oraz Stowarzyszenie Przyjaciół UŚ i Instytut Historii UŚ. Wygłoszono ok. 70 referatów podczas sesji plenarnych w ramach sekcji i paneli dyskusyjnych (najwięcej w sekcji szkolnictwo i oświata - 14 referatów, pozostałe dotyczyły społeczeństwa, polityki zagranicznej, życia religijnego (12 referatów). Tylko jeden z referatów poświęcony był w całości wydarzeniom roku

\footnotetext{
${ }^{15}$ Koło Naukowe Historyków Studentów Uniwersytetu Jagiellońskiego, http://knhs.hist.uj.edu.pl/index.php/ start/58/191-konferencja-od-okrgego-stou-do-iiirpq.

${ }^{16}$ Instytut Historii i Stosunków Międzynarodowych US, http://www.szczecin.eu/przelomy/kalendarz_wydarzen/89/oblicza_polskiej_modernizacji_bilans_transformacji_systemowej_iii_rp.html. Wydanie książkowe: Oblicza polskiej modernizacji. Próba transformacji systemowej III RP, red. E. Krasucki, T. Sikorski, A. Szczepańska, Toruń 2010.

${ }^{17}$ Kongres Politologii, http://www.kongrespolitologii.pl/program. Por.: Polski rok 1989. Sukcesy, zaniechania, porażki, red. M. Jabłonowski, S. Stępka, S. Sulowski, Warszawa 2009.
} 
1989 (Adam Suchoński - Wydarzenia roku 1989 w Polsce na kartach zagranicznych podręczników do nauczania historii) $)^{18}$.

W czasie drugiej konferencji („Dwa dwudziestolecia. Społeczeństwo, państwo, geopolityka"), której organizatorem był Zakład Najnowszej Historii Politycznej Wydziału Nauk Politycznych i Dziennikarstwa UAM, wygłaszane referaty (ok. 50) ogniskowały się wokół trzech zarysowanych w tytule konferencji zagadnien, a trzy z nich dotyczyły tylko roku 1989 (W. Mazurczak - Polska w Europie - geneza i konsekwencje 1989 roku, J. Kufel - Kampania wyborcza kandydatów KO Solidarność na tamach „Gazety Wyborczej” przed wyborami czerwca 1989 w Polsce i K. Robakowski - Ruch ludowy w 1989 roku) ${ }^{19}$.

W kilku konferencjach (przede wszystkim UJ, UAM) brali udział członkowie studenckich kół naukowych, a w wypadku studentów politologii UAM zakończyło się to wydaniem osobnej monografii ${ }^{20}$.

Przeglądając monografie dotyczące roku 1989 w historii Polski, stwierdzić trzeba za jednym z autorów, że dekada lat 80-tych, zamykająca czasy PRL należy do najlepiej i najpełniej opracowanych okresów w najnowszej historii Polski ${ }^{21}$. Oprócz wymienionych wyżej pozycji w roku 2009 ukazały się m.in. autorskie monografie naukowe: J. Skórzyńskiego, A. Friszke i P. Codogni ${ }^{22}$. Warte zauważenia są także niesłychanie ciekawe i bardzo dobrze opracowane wydawnictwa źródłowe ${ }^{23}$. Ukazało się też sporo wydawnictw okolicznościowych wydanych przez instytucje państwowe, NSZZ Solidarność, ośrodki kultury, urzędy marszałkowskie. Są to $\mathrm{z}$ reguły materiały z konferencji oraz wspomnienia działaczy $\mathrm{z}$ tamtego okresu.

Natomiast odnotować musimy brak większego zainteresowania omawianą problematyką ze strony czasopism naukowych. $Z$ tej okazji z reguły ukazywały się jedynie pojedyncze artykuły. W „Dziejach Najnowszych” tylko dwa w numerze czwartym (ww. artykuł bibliograficzny R. Sudzińskiego i T. Kisielewskiego o stanie świadomości politycznej w partii w okresie obrad okragłego stołu). Warto w tym miejscu podkreślić, że poprzedni numer został całkowicie poświęcony wybuchowi II wojny światowej i być może, dlatego sił zabrakło dla jeszcze jednego numeru specjalnego. Z kolei w „Przeglądzie Politologicznym” ukazało się jedynie krótkie sprawozdanie E. Lesiewicz z konferencji organizowanej przez WNPiD UAM. Wyjątkiem był „Ruch Prawniczy, Ekonomiczny i Socjologiczny”, który nr 2 w 2009 roku jako numer specjalny, poświęcił dwudziestoleciu transformacji w Polsce. Dominowały tam jednak artykuły dotyczące wydarzeń już po 1989 roku.

Rok 1989 doczekał się najszerszego omówienia w czasopiśmie „Arcana. Kultura, historia, polityka". W numerze 2-3 z 2009 roku znalazły się dwa bloki tematyczne: 1989 - czas kon-

\footnotetext{
${ }^{18}$ Uniwersytet Śląski, http://www.sp.us.edu.pl/files/program\%20konferencji\%20poprawny.pdf. Wydanie książkowe: Dwa Dwudziestolecia Rzeczypospolitej, t. I: Oświata - religia - kultura i spoleczeństwo. Próba bilansu, red. M. Fic, L. Krzyżanowski, M. Skrzypek, Katowice 2010; t. II: Polityka-prawo i administracja-gospodarka. Próba bilansu, red. M. Fic, L. Krzyżanowski, M. Skrzypek, Katowice 2010.

${ }^{19}$ Dwa dwudziestolecia. Geopolityka. Państwo. Społeczeństwo, red. P. Hauser, W. Mazurczak, Poznań 2010.

${ }^{20}$ Wokót dwóch dwudziestoleci. Prace studenckiego Koła Naukowego Historii Najnowszej WNPiD UAM, red. E. Lesiewicz, W. Mazurczak, Poznań 2011.

${ }^{21}$ R. Sudziński, Rok 1989 w historiografii polskiej - z perspektywy dwudziestolecia, „Dzieje Najnowsze” 2009,

${ }^{22}$ J. Skórzyński, Rewolucja okragtego stolu, Kraków 2009; A. Friszke, Rok 1989: polska droga do wolności, Warszawa 2009; P. Cadogni, Okragly stót czyli Polski Rubikon, Warszawa 2009; J. I. Gross, Rok 1989: koniec społeczeństwa nieobywatelskiego, Warszawa 2009.

${ }^{23}$ Zmierzch dyktatury. Polska lat 1986-1989 w świetle dokumentów, t. I (lipiec 1986-maj 1989), t. II (czerwiec-grudzień 1989), wybór, wstęp i opracowanie A. Dudek, Warszawa 2009 i 2010; Upadek Peerelu 1986-1989, wybór i opr. A. Dębska, Warszawa 2009.
} nr 4, s. 94. 
wergencji: różne perspektywy oraz Gospodarze ,okragłego stołu”. Pierwszy zawierał trzy artykuły: Henryk Głębocki - Jak znaleźć numer telefonu na Kreml? Rosja w strategii politycznej ,,konstruktywnej opozycji” w PRL (1985-1989), Tomasz Mianowicz - 1989: Transformacja - konwergencja i Paweł Wierzbicki - Strategie polityczne opozycji demokratycznej wobec władz PRL w latach 1986-1989. Uzupełnieniem były wspomnienia Jerzego Rosia, działacza NZS o wydarzeniach w lutym 1989 roku w Krakowie. Materiały umieszczone w drugim bloku to właściwie tylko szerokie omówienie dokumentów związanych z wizytą Ericha Mielke w Warszawie 17-18 marca 1982 roku, analiza dokumentów z kontroli operacyjnej V Ogólnopolskiego Zjazdu Socjologicznego w styczniu 1977 r. w Krakowie i uwagi nad biografią M. F. Rakowskiego oraz fragment powieści Henryka Skwarczyńskiego Jak zabiłem Piotra Jaroszewicza. Ta część już dość luźno była związana z rocznicą 1989 roku. W sumie jednak redakcja „Arcanów”, pisma sytuującego się po prawej stronie sceny politycznej, poświęciła rocznicy 209 stron, a więc sporo w porównaniu z innymi.

Refleksja naukowa pozostawała w cieniu uroczystości organizowanych przez instytucje państwowe. Były one szczególną okazją do kreowania ,polityki pamięci’ w najściślejszym sensie tego słowa. W warunkach ostrego konfliktu politycznego, który zdominował polską sferę publiczną w końcu drugiej dekady III RP musiały one stać się również kolejnym polem starcia różnych wizji upamiętnianych wydarzeń.

Niewątpliwie służyły temu uroczyste obchody 20. rocznicy obrad Okrąłłego Stołu w Polsce. Na szczeblu oficjalnym należała do nich Uchwała Sejmu RP z 23 stycznia 2009 r. w sprawie uczczenia rocznicy rozpoczęcia obrad Okragłego Stołu i odzyskania przez Polskę wolności. Sejm wyraził w specjalnej uchwale uznanie dla „mądrości i dalekowzroczności” uczestników rozmów Okragłego Stołu. 5 lutego 2009 roku. Zarówno w Sejmie, jak również w siedzibie Prezydenta RP zorganizowano przy tej okazji, wspomniane we wcześniejszej części tekstu, alternatywne konferencje. Uroczystości związane z obchodami 20. rocznicy obrad Okragłego Stołu były stosunkowo skromne, zaważyły zapewne w tej kwestii polityczne spory, osobiste urazy i różnica w interpretacji obrad, i znaczenia Okrąłego Stołu przez różne ugrupowania polityczne.

20 rocznicę pierwszych wolnych wyborów w Polsce, które odbyły się 4 czerwca 1989 roku obchodzono ze zdecydowanie większym zaangażowaniem instytucji państwowych, choć nie obyło się bez kontrowersji. Koordynatorem uroczystości było Narodowe Centrum Kultury. W organizację obchodów zaangażowały się również liczne państwowe instytucje, m.in. Ministerstwo Kultury i Dziedzictwa Narodowego, Europejskie Centrum Solidarności, Rada Ochrony Pamięci Walk i Męczeństwa, Muzeum II Wojny Światowej, IPN, Biblioteka Narodowa, urzędy wojewódzkie i marszałkowskie, a także urzędy miast i gmin. Obchody zorganizowane były we współpracy z Ministerstwem Spraw Zagranicznych i Instytutami Polskimi za granicą. Główne działania instytucji biorących udział w tym przedsięwzięciu zmierzały do zwrócenia uwagi Europejczyków na to, jak wiele wydarzeń, które wpłynęły na kształt współczesnej Europy, zaczęło się w Polsce, z jak wielu elementów swojej historii Polacy mogą być dumni. Hasłem kampanii promocyjnej była fraza „Zaczęło się w Polsce”, podkreślająca historyczny wymiar obchodów. Z kolei hasło pomocnicze brzmiało: „Niemożliwe jest możliwe"24.

Jednak od samego początku obchody te wzbudzały wiele kontrowersji, bowiem pierwotnie zaplanowano zorganizować je pod Pomnikiem Poległych Stoczniowców w Gdańsku. Tam też

\footnotetext{
${ }^{24}$ Portal Onet pl. 28 V 2009, http://wiadomosci.onet.pl/regionalne/trojmiasto/obchody-20-rocznicy-odzyskania-wolnosci-i-upadku-k,1,3510599, wiadomosc.html.
} 
miało dojść do spotkania przedstawicieli delegacji zagranicznych z młodzieżą. Tymczasem na ten sam dzień i w tym samym miejscu „Solidarność” zapowiedziała manifestację w obronie stoczni i miejsc pracy. Premier Donald Tusk w obawie przed zamieszkami zdecydował się przenieść obchody do Krakowa ${ }^{25}$. Ostatecznie główne uroczystości rocznicowe odbyły się w Krakowie z udziałem premiera i w Gdańsku z udziałem prezydenta.

3 czerwca 2009 roku w Sejmie z okazji 20. rocznicy obalenia komunizmu w Polsce zorganizowano specjalną wystawę oraz uroczyste posiedzenie posłów i senatorów. Udział w tych wydarzeniach wzięli m.in. premier Donald Tusk, Lech Wałęsa, Aleksander Kwaśniewski, Tadeusz Mazowiecki, marszałkowie Sejmu i Senatu: Bronisław Komorowski i Bogdan Borusewicz oraz przedstawiciele parlamentów 24 europejskich państw i szef Parlamentu Europejskiego Hans-Gert Poettering. Nie obyło się jednak bez politycznych utarczek. Lech Kaczyński, choć był zaproszony, nie zaszczycił swoją obecnością wspólnego posiedzenia posłów i senatorów. Prezydent obejrzał w Sejmie jedynie wystawę zdjęć Polska droga do wolności 1980-1989. Jednocześnie dał do zrozumienia, że na uroczystości rocznicowe pojedzie do Gdańska ${ }^{26}$.

Krakowskie obchody poprzedziło dzień wcześniej spotkanie przedstawicieli państw Grupy Wyszehradzkiej w Wieliczce. 4 czerwca uroczystości przeniesiono na Wawel. Do Krakowa zjechali przywódcy europejskich państw, m.in. kanclerz Niemiec Angela Merkel, premier Ukrainy Julia Tymoszenko i premier Czech Jan Fischer. Wśród gości są także byli prezydenci Lech Wałęsa i Aleksander Kwaśniewski, byli premierzy Jerzy Buzek, Leszek Miller, Józef Oleksy i Kazimierz Marcinkiewicz. Do zebranych gości w Katedrze Wawelskiej przemawiał biskup krakowski ks. kard. Stanisław Dziwisz. Następnie rozpoczęły się uroczystości na dziedzińcu arkadowym na Wawelu. Premier Donald Tusk dziękował żyjącym i nieżyjącym już, znanym i anonimowym, bohaterom walki o wolność Polski ${ }^{27}$. Lech Wałęsa apelował, aby cieszyć się i świętować zakończenie podziałów. Podkreślił, że przemiany demokratyczne były możliwe, ponieważ podczas ich dokonywania oparto się na wartościach. Angela Merkel oświadczyła, że 4 czerwca jest dniem historycznym, świętem nie tylko dla Polski, ale i dla całej Europy. Vaclav Havel ocenił, że rocznica wyborów 1989 r. w Polsce jest również okazją do tego, by wysłać znak solidarności z narodami, które nadal walczą o wyzwolenie. O znaczeniu wydarzeń sprzed dwudziestu lat dla całej Europy i świata mówili także inni zaproszeni przywódcy ${ }^{28}$.

Tymczasem w Gdańsku Lech Kaczyński rano w sali „Akwen” Komisji Krajowej NSZZ „Solidarność” wręczył odznaczenia osobom zasłużonym dla przemian demokratycznych i wyraził żal, że 20. rocznica wyborów 4 czerwca 1989 roku to nie jest święto wspólne $i$ wszystkich. Następnie pod pomnikiem Poległych Stoczniowców w Gdańsku rozpoczęła się msza św. celebrowana przez prymasa Polski Józefa Glempa współorganizowana przez NSZZ „S”. We mszy uczestniczyło ok. 3 tys. osób, m.in. prezydent Lech Kaczyński, prezes PiS Jarosław Kaczyński, szef „S” Janusz Śniadek.

Po południu w Gdańsku z udziałem Donalda Tuska i Lecha Wałęsy w sali Polskiej Filharmonii Bałtyckiej na wyspie Ołowianka rozpoczęła się międzynarodowa konferencja „Soli-

\footnotetext{
${ }^{25}$ Portal Gazeta pl. 7 V 2009, 2009http://wiadomosci.gazeta.pl/wiadomosci/1,114873,6581025,Premier_przeniosl_obchody_do_Krakowa.html.

${ }^{26}$ Dziennik 3 VI 2009, http://wiadomosci.dziennik.pl/polityka/artykuly/151277,prezydent-zbojkotowal-obchody-4-czerwca.html.

${ }^{27}$ Portal MM Moje Miasto Kraków 5VI 2009, http://www.mmkrakow.pl/340573/2009/6/4/modo-wawel-zakonczyly-sie-obchody-rocznicy-obalenia-komunizmu-fotowideo?category=video.

${ }_{28}$ Wprost 4 VI 2009, http://www.wprost.pl/ar/163164/20-rocznica-wyborow-4-czerwca-w-Krakowie-i-Gdansku/.
} 
darność i upadek komunizmu", ukazująca rolę i znaczenie Polski w przemianach 1989 roku w Europie. Wieczorem odbył się koncert Zaczęło się w Polsce z udziałem polskich i zagranicznych artystów ${ }^{29}$.

Wystawy, koncerty, imprezy plenerowe, parady, przemarsze, a nawet biegi oraz spotkania z działaczami dawnej opozycji znalazły się w programach obchodów 20. rocznicy wyborów 4 czerwca, przygotowywanych przez miasta z całego kraju. Wymieńmy niektóre z nich. Warszawa rocznicę wyborów uczciła cyklem imprez kulturalnych odbywających się wzdłuż Krakowskiego Przedmieścia. Należały do nich m.in. wystawa plenerowa, widowisko uliczne inspirowane poezją opozycyjną, kino plenerowe. W Zielonej Górze 4 czerwca odbyła się uroczysta sesja sejmiku województwa lubuskiego, podczas której zostały wręczone tytuły Honorowego Obywatela Województwa Lubuskiego reprezentantom województwa, którzy w wyborach czerwcowych dostali się do parlamentu z ramienia Komitetu Obywatelskiego „Solidarność”. 4 czerwca w ścianę budynku w Kielcach, gdzie mieściła się siedziba Komitetu Obywatelskiego, została wbudowana pamiątkowa tablica. W świętokrzyskim Jędrzejowie 4 czerwca odbył się bieg „Ku demokracji” oraz zawody sportowe dla dzieci i młodzieży. Krakowskie obchody rocznicy wyborów rozpoczęły się już 19 maja. Wtedy została otwarta wystawa zdjęć z kampanii wyborczej, plakatów, ulotek i biuletynów wyborczych „Solidarności”. Odbyło się także spotkanie Lecha Wałęsy, Tadeusza Mazowieckiego i innych członków Komitetów Obywatelskich ze studentami krakowskich uczelni. W Katowicach tysiące pomarańczowych baloników wypuszczono w niebo w ramach projektu „Lot ku wolności”. Nawiązywał on do akcji balonowej przeprowadzonej 5 marca 1982 r., kiedy z plaż Bornholmu działacze polskiej opozycji, Francuzi i Duńczycy wypuścili w powietrze 10 tys. baloników, które zaniosły do Polski ulotki z nieocenzurowanymi bieżącymi informacjami. Urząd Wojewódzki w Katowicach zorganizował plenerowe miasteczko PRL z częścią reżimową, do której wstęp był możliwy po wylegitymowaniu się oraz częścią wolnościową, z repliką Okragłego Stołu i urnami do głosowania. Zabytkowy autobus woził również chętnych „trasą wolności” m.in. do Muzeum Izby Pamięci Kopalni „Wujek” i pomieszczeń dawnego aresztu śledczego. 5 czerwca Śląski Urząd Miejski przygotował koncert pod hasłem Proszę Państwa, 20 lat temu skończył się u nas komunizm, w którym uczestniczyła autorka tytułowego zdania Joanna Szczepkowska, a gwiazdą wieczoru był Bob Geldof ${ }^{30}$.

W Lublinie ustawiono 170 urn przypominających o wyborach sprzed 20 lat. Symbolem tego, co się wtedy wydarzyło w Polsce jest urna wyborcza. Urn było 170 - tyle, ile w 1989 r. było komisji wyborczych w Lublinie. W Szczecinie obchody rocznicowe rozpoczęto toastem przed Urzędem Miasta wzniesionym przez władze i mieszkańców miasta czerwoną oranżadą - napojem symbolem PRL-u. Otwarto wystawę plenerową pt. 1989. Narodziny wolności. Wybory 4 i 18 czerwca 1989 w Szczecinie. Po szczecińskich ulicach jeździł też zabytkowy tramwaj, wewnątrz którego można było oglądać plakaty wyborcze z 1989 roku. W Radomiu w Ośrodku Kultury i Sztuki Resursa Obywatelska otwarta została wystawa Wybory 4 czerwca 1989 r. w Radomiu i regionie, przygotowana wspólnie z radomską delegaturą Instytutu Pamięci Narodowej. Prezentowany był też specjalnie przygotowany na jubileuszowe obchody film Radom 1989-2009. Również w Jarocinie, można było obejrzeć wystawę poświęconą miastu i jego mieszkańcom, tyle że pokazującą rzeczywistość sprzed 1989 r. Ekspozycja pt. Jarocin w cieniu PRL to fotografie pierwszomajowych pochodów, obchodów święta 22 lipca,

\footnotetext{
${ }^{29}$ Ibidem.

30 Twój Śląski Portal 6VI 2006, http://www.esil.pl/symboliczne-pozegnanie-komunizmu,wiadomosci,e,15212.html, http://www.rp.pl/artykul/304373,306342-Przygotowania-do-20_rocznicy-wyborow.html.
} 
festynów, a także sceny z życia codziennego. Z myślą o młodych ludziach rzeszowski IPN przygotował pogadankę Wybory parlamentarne w 1989 r. w województwie rzeszowskim. W Kielcach kilkudziesięciu licealistów wzięło udział w edukacyjnym „Marszu wolności”, zorganizowanym pod hasłem 4 czerwca '89'09 - Kielce - Znaki czasu i pamięci. W Łodzi zaprezentowano specjalnie wydaną publikację Nasze 53 dni $i$ dwa tygodnie - 4 czerwca '89; znalazły się w niej zdjęcia i plakaty wyborcze, a przede wszystkim wspomnienia łódzkich kandydatów i działaczy sztabu wyborczego Wojewódzkiego Komitetu Obywatelskiego „Solidarność" w Łodzi. W Olsztynie Rada Miasta podczas uroczystej sesji podjęła uchwałę, w której oddała hołd wszystkim, którzy przyczynili się do powstania niepodległej Polski w 1989 roku. W Poznaniu spotkali się działacze Komitetów Obywatelskich działających w Wielkopolsce w 1989 roku. Spotkanie poprzedziła msza święta w intencji ojczyzny oraz złożenie kwiatów pod pomnikiem Czerwca 1956 roku. Uroczyste msze święte odprawiono też w innych miastach Polski. W Bydgoszczy w Filharmonii Pomorskiej odbył się rocznicowy koncert upamiętniający tych, którzy przyczynili się do zniesienia żelaznej kurtyny ${ }^{31}$. Wiele z przedstawionych imprez odbyło się niestety w cieniu kontrowersji wynikających z podziałów politycznych i prób politycznego wykorzystania uroczystości.

W dwudziestolecie wydarzeń z 1989 roku prasa skupiła się przede wszystkim na analizie obchodów rocznicy wyborów czerwcowych do parlamentu oraz konsekwencjach obrad Okragłego Stołu. Wiele miejsca, szczególnie na łamach „Gazety Wyborczej” poświęcono także porównaniu dwóch dwudziestoleci, tj. 1918-1939 i 1989-2009. Ponadto wspomniany wyżej dziennik upamiętnił wydanie swego pierwszego numeru w maju 1989 roku.

Media z zainteresowaniem komentowały przygotowania oraz właściwe obchody 20-lecia czerwca 1989 roku, które odbyły się w Krakowie i Gdańsku. Pokazały obraz współczesnej Polski, która po dwóch dekadach od przełomowych wydarzeń nie potrafi się zjednoczyć. Kraju, w którym więzi międzyludzkie są nadal słabe, co widoczne było szczególnie na szczytach władzy. Pisano o Polsce podzielonej na wyższa kulturowo półkę (czyli PiS) i niższa pozbawioną cnót patriotycznych, jak to określił prezes Jarosław Kaczyński ${ }^{32}$ lub na my i oni, z czego my w myśl Jana Marii Jackowskiego stanowili zwykli ludzie skupieni przed gdańskimi krzyżami na uroczystej mszy świętej ${ }^{33}$. Z kolei dla Pawła Śpiewaka obchody rocznicowe w 2009 roku uwydatniły podział na ,, nas " społeczeństwo $i$,, onych” władzę $e^{34}$. Autor ten w artykule zamieszczonym na łamach tygodnika „Wprost” uznał przeniesienie uroczystości z Gdańska do Krakowa za nietakt i fatszowanie historii ${ }^{35}$. Można zaryzykować stwierdzenie, że głosy te uwypukliły istnienie grup nawiązujących do tradycji III i IV RP.

W prasie wiele miejsca poświęcono dwudziestej rocznicy obrad przy Okragłym Stole. Przypomniano decyzje, które wówczas podjęto oraz atmosferę towarzyszącą temu wydarzeniu. W tygodniku „Polityka” opublikowano wspomnienia o ludziach zasiadających przy Okragłym Stole ${ }^{36}$. M. Hensler przybliżył aktywność najważniejszych aktorów tych obrad po 20 latach od tego zdarzenia. Wśród nich byli przedstawiciele strony rządzącej (w tym na przykład: Aleksander Kwaśniewski, Czesław Kiszczak, Alfred Miodowicz) i opozycyjnej

\footnotetext{
${ }^{31}$ Portal Polska Lokalna w Interia pl, 4 VI 2009, http://polskalokalna.pl/wiadomosci/mazowieckie/warszawa/news/obchody-20-rocznicy-wyborow-4-czerwca-1989-r-w-polsce,1318319,3319.

32 J. Paradowska, Naturalne święto, „Polityka”, nr 24 z 13.06.2009 r.

33 J. M. Jackowski, Wybory 4 czerwca 1989 roku - zwycięstwo kontrolowane. Pokłosie Magdalenki, ,Nasz Dziennik", nr 130 z 4.06.2009 r.

${ }^{34}$ P. Śpiewak, Kłamstwo czerwcowe, ,Wprost”, nr 23 z 7.06.2009 r.

${ }^{35}$ Ibidem.

${ }^{36}$ M. Hensler, Lista obecności: ludzie Okragłego Stołu, „Polityka”, nr 1 z 3.01.2009 r.
} 
(np. Lech Wałęsa, Tadeusz Mazowiecki, Zbigniew Bujak) oraz obserwatorzy kościelni (księża Bronisław Dembowski, Janusz Narzyński, Alojzy Orszulik). W artykule podkreślono, że spośród 58 uczestników tych obrad 21 nie żyje, 19 jest na politycznej emeryturze, a 18 pozostałych jest nadal aktywnych politycznie.

Dziennikarze, publicyści i naukowcy na łamach prasy odnieśli się także do wyborów z 1989 roku, które dla jednych były punktem zwrotnym w dziejach naszego państwa i zapowiedzią wolności, a dla drugich faktem bez większego znaczenia z uwagi na trwanie nadal w komunistycznych okowach.

W opinii Jana Marii Jackowskiego 4 czerwca był dniem, w którym PRL zaczą się instytucjonalnie przekształcać w system realnego postkomunizmu ${ }^{37}$. Autor zastanawiał się czy wspomniany wcześniej dzień oznaczał obalenie komunizmu czy był jedynie początkiem długiej drogi wychodzenia z niego już od ponad 20 lat. Dylemat ten towarzyszył także rozważaniom innego dziennikarza „Naszego Dziennika”, a mianowicie Sebastiana Karczewskiego. Uznał on świętowanie jubileuszu upadku komunizmu w rocznicę czerwcowych wyborów za nieporozumienie $^{38}$. Stwierdził, że po dzień dzisiejszy komuniści mają wpływ na władzę, a Tadeusz Mazowiecki nie potrafił zerwać z niechlubnym dziedzictwem PRL. O kontynuacji PRL po czerwcowych wyborach w 1989 roku przekonany był także historyk Sławomir Cenckiewicz $^{39}$. Dla niego 4 czerwca stanowił mit założycielski III RP. Z kolei zdaniem Lecha Kaczyńskiego ważniejsza od 4 czerwca była data 12 września, kiedy powołano rząd Tadeusz Mazowieckiego i odbierano komunistom większość władzy ${ }^{40}$. Odmienne zdanie zaprezentował Adam Michnik, uznając w ogóle rok 1989 za rok cudów, a wybory 4 czerwca za zwycięstwo demokracji nad komunizmem ${ }^{41}$. Po 20 latach od tamtych wydarzeń napisał, iż w 1989 roku Polacy pokazali światu twarz najlepszq - odważna i tolerancyjnq. Twarz narodu, który sam siebie potrafi zmienić na lepsze $e^{42}$.

W gazetach, oprócz opisów sytuacji politycznej i ekonomicznej poprzedzającej akt wyborczy, publikowano także wspomnienia ludzi zaangażowanych w wybory 4 czerwca 1989 roku. W dyskusję, na łamach prasy, podsumowującej dwudziestolecie wolnej Polski włączyli się między innymi Antoni Dudek, Rafał Matyja oraz Aleksander Hall. Ten ostatni zastanawiał się czy w 1989 roku w starciu z upadajacym PRL ,, Solidarność” mogła wywalczyć więcej? ${ }^{43}$ Z perspektywy dwóch dekad można bowiem spotkać się z krytyką postaw liderów solidarnościowych za zbyt ostrożna postawę przyjęta po wyborach. Jej wyrazem była między innymi, jak pisze A. Hall, zgoda na wybór prezydenta przez Zgromadzenie Narodowe. Autor przyznaje jednak, że w 1989 roku Polska odniosła swój największy sukces w XX wieku. W specjalnym dodatku zatytułowanym Zaczęło się w Polsce do „Rzeczypospolitej” swoimi przeżyciami dzieliły się także osoby ze świata kultury i sztuki. Wśród nich byli na przykład Kazimierz Kaczor (aktor), Wojciech Młynarski (poeta), Jan Pietrzak (satyryk) i Kora (piosenkarka). W dodatku tym przypomniano także skład Sejmu kontraktowego i Senatu ${ }^{44}$.

\footnotetext{
${ }^{37}$ J. M. Jackowski, op. cit.

${ }^{38}$ S. Karczewski, Solidarność bez solidarności, „Nasz Dziennik”, nr 130 z 4.06 .2009 r.

${ }^{39}$ Mit założycielski III RP, rozmowa Mariusz Bobera z dr Sławomirem Cenckiewiczem, historykiem i publicysta, współautorem ksiażki ,,SB a Lech Wałęsa. Przyczynek do biografii”, „Nasz Dziennik”, nr 130 z 4.06.2009 r.

404 czerwca nie skończyt się komunizm, rozmowa I. Janke z Lechem Kaczyńskim, „Rzeczpospolita”, nr 1340 z 4.06.2009 r.

${ }^{41}$ A. Michnik, Święto wolności, „Gazeta Wyborcza”, nr 130 z 4 czerwca 2009 r.

${ }^{42}$ Ibidem.

43 A. Hall, Okragly Stót - ani rewolucyjny zryw, ani kapitulacja, „Dziennik” z 30.01.2009 r.

44 Zaczęto się w Polsce, dodatek do „Rzeczypospolitej” z czerwca 2009 r., s. 16-17.
} 
Paweł Śpiewak w swoim artykule opublikowanym w tygodniku „Wprost” zwrócił uwagę na inny fakt, a mianowicie ponowną legalizację NSZZ „Solidarności” 17 kwietnia 1989 roku $^{45}$. Akt ten zdaniem autora był symbolicznym zwycięstwem nad komunizmem, bo dowo$d z i t$, ze mimo stanu wojennego zwiazek przetrwat jako znak sprzeciwu wobec reżimu. Uznając doniosłość tego związku dla przeobrażeń w Polsce przyznał jednak, że obecnie jest on instrumentem wykorzystywanym przez wszystkie polityczne opcje.

Wiele miejsca na łamach „Gazety Wyborczej” zajęło porównanie dwóch dwudziestoleci - tego z okresu międzywojennego i po 1989 roku. Konfrontacji poddano położenie międzynarodowe oraz sytuację społeczno-ekonomiczną w II i III RP. Nawiązano do roli mediów szczególnie przed wyborami, które w pierwszym okresie spełniał kościół (ogłoszenia parafialne), a później rodząca się wolna prasa („Gazeta Wyborcza”). Skupiono się także na zaangażowaniu społeczeństwa w wyborach do parlamentu, które w 1919 roku było większe (78\% frekwencja) niż w 1989 roku (o 15\% mniej). Ponadto Tomasz Nałęcz odniósł się do istnienia dwóch wizji (Piłsudskiego i Endecji) na początku II RP i jej braku w III RP. Pisał o przełomie cywilizacyjnym po 1989 roku, czego nie było z kolei po I wojnie światowej. Analizie poddano także kwestie narodowościowe oraz pozycję kościoła w dwóch okresach. Nawiązywano do problemów socjalnych i społecznych, które po 1989 roku miały inny wymiar. Tematem rozważań był również patriotyzm, który zdaniem Zbigniewa Ścibora-Rylskiego (prezesa Zarządu Głównego Związku Powstańców Warszawskich urodzonego pod zaborami) był bardzo cennym uczuciem, większym niż obecnie ${ }^{46}$.

Na łamach „Polityki” i „Rzeczpospolitej” przypomniano także, iż w 1989 roku (dokładnie 8 maja) ukazał się pierwszy numer „Gazety Wyborczej”. Z okazji jubileuszu „Gazeta Wyborcza" przygotowała specjalny dodatek zatytułowany 20 przygód Gazety w Trzeciej i Czwartej $R P$. Temu towarzyszyła także okolicznościowa kolekcja z Dziełami wybranymi Adama Michnika. Nie zapomniano również o „Tygodniku Solidarność”, który w czerwcu 1989 roku pojawił się ponownie po zawieszeniu jego wydawania przez władze PRL.

Niewiele miejsca poświęcono natomiast konsekwencjom czerwcowych wyborów, a mianowicie powołaniu rządu Tadeusza Mazowieckiego. Bez większego rozgłosu przeszły także nowelizacje konstytucji, w następstwie których z ustawy zasadniczej zniknęły słowa: „socjalizm” i „przewodnia rola partii”, a ponadto dokonano zmiany nazwy państwa z Polskiej Rzeczypospolitej Ludowej na Rzeczpospolitą Polską. Nie odnotowano faktu powrotu do instytucji prezydenta ani przywrócenia Senatu, który w wyniku referendum z 30 czerwca 1946 roku został zlikwidowany. Pisano jedynie o tej izbie w kontekście wolnych wyborów, a nie jej powrotu na scenę polityczną. Nie uwypuklono ponadto faktu zmiany w herbie Polski mocą tzw. noweli grudniowej z 29 grudnia 1989 roku.

Podsumowując można stwierdzić, iż upamiętnienie dwudziestej rocznicy 1989 roku w polskiej prasie było silnie skorelowane $\mathrm{z}$ orientacją polityczną czasopism. Komentarze w prasie pozytywnie odnosiły się do przemian, których byliśmy świadkami w ostatnich latach w Polsce, ale w części z nich optymizm przyćmiony był wizją ciągłej obecności komunistów we władzy.

Obchody rocznicy narodzin III Rzeczypospolitej, mimo dużego rozmachu organizacyjnego, nie stały się raczej powodem do spontanicznego narodowego świętowania. Potwierdził się, dawno już opisywany, syndrom faktycznego braku obecności w świadomości Polaków

\footnotetext{
${ }^{45}$ P. Śpiewak, op. cit.

${ }^{46}$ Byliśmy dumni, że będziemy walczyć!, ,Super Ekspres” z 24.11.2009 r., http://www.se.pl/wydarzenia/opinie/bylismy-dumni-ze-bedziemy-walczyc_119918.html.
} 
daty 1989 roku, jako pokoleniowego przeżycia, pozytywnie organizującego ich pamięć zbiorową. Zaważył na tym być może brak w tejże pamięci wydarzenia, które jednoznacznie kojarzyłoby się z przełomem, zrywało ciagłość dziejową. Nie stała się nim ciągle, wbrew diagnozie D. Gawina, rocznica wyborów czerwcowych 1989 roku $^{47}$. Zabrakło w związku z tym świadomości rewolucyjnego charakteru dokonujących się zmian. Ważniejsze dla opisywanego deficytu było chyba zjawisko, które obserwować można na podstawie opisanych w niniejszym tekście imprez i odniesień rocznicowych. Chodzi o odstręczającą atmosferę politycznego sporu i prób zawłaszczania wspólnego dobra, na które składa się przełom roku 1989 i odmiana oblicza kraju w następnych dwu dekadach. W takich okolicznościach opinia publiczna odbierała uroczystości rocznicowe ze znużeniem i dużą dozą obojętności. Czy pomimo to dwudziesta rocznica istnienia III Rzeczypospolitej stała się okazją do narodowej refleksji nad dorobkiem epoki zapoczątkowanej wydarzeniami roku 1989? W jakimś zakresie zapewne tak, choć satysfakcja z dziejowego sukcesu była współcześnie mniej widoczna niż w II Rzeczypospolitej, podczas obchodów jubileuszowych w roku 1928 (w 1938 atmosfera była już mocno zakłócona groźbą nadciągającej wojny). Nastrój społeczeństwa podlegał wpływowi działań i słów zwalczających się obozów politycznych, które nie wahały się wykorzystywać obchodów rocznicowych dla swych doraźnych, partykularnych celów. Widać to wyraźnie na przykładzie konsekwentnego organizowania konferencji, akademii, spotkań i innych uroczystości wokół dwóch wrogich wobec siebie obozów: prezydenckiego i rządowego. Starannie dobierano przy tej okazji reprezentacje naukowców biorących w nich udział. Konferencje stricte naukowe odbywały się w cieniu tamtych wydarzeń.

Nie było jednak między stronami sporu pełnej symetrii. Silniej dochodziły do opinii publicznej radykalne głosy, odmawiające odrodzonemu po 1989 roku państwu prawa do bycia przedmiotem dumy Polaków. Czarna wersja ,polityki pamięci” wybrzmiewała w publicznej przestrzeni głośno i wyraźnie, i rozbijała, niszczyła „,narodowy konsens dumy” z odrodzonego państwa, jakże przecież widoczny w II Rzeczpospolitej, mimo wszystkich trapiących ją bolączek. Uroczystości państwowe oraz organizowane przez rozmaite środowiska i stowarzyszenia były stosunkowo liczne, jednak refleksja naukowa wyrażona podczas konferencji i seminariów oraz debata prasowa zdają się nie być odpowiednio intensywne w stosunku do rangi upamiętnianych zdarzeń. Czy powstało dzieło o tak dużym rezonansie jak słynna, wydana w 1928 roku, okolicznościowa księga na dziesiątą rocznicę II Rzeczypospolitej? Nie! Te zaś publikacje, które ujrzały światło dzienne z całą pewnością nie osiagnęły podobnego statusu. Fakt ten może służyć jako podsumowanie ułomnego - mimo wszystko - charakteru uroczystości rocznicowych III Rzeczypospolitej. Tak oto bieżąca polityka zakłóciła obraz jednego z większych dziejowych sukcesów, które stały się udziałem polskiego społeczeństwa.

\section{Summary}

\section{The celebrations of the twentieth anniversary of the Third Polish Republic. The attempts to shape Polish society's collective memory}

The paper tries to sum up the celebrations to commemorate the twentieth anniversary of the Third Republic in 1989 and to present them in the context of the 'remembrance policy',

${ }^{47}$ D. Gawin, op. cit., s. 30. 
meaning the endeavors various circles are engaged in to shape Polish society's collective memory. The authors analyze the celebrations in terms of several selected aspects. The first one concerns the academic field: conferences, seminars and resulting publications. Another aspect refers to the official celebrations organized by state institutions. The third is about the response and debates taking place in newspapers at that time. The review of different ways of commemorating the anniversary results in the conclusion that they were all strongly politicized and used for the purposes of the current political struggle. This was particularly clear during the official celebrations, divided into those organized by the government and president respectively, yet even the events organized under academic auspices were not free from political manipulation. Therefore, the celebrations corroborated the fact that 1989 has not strongly registered in Poles' awareness as a generational experience that positively organizes the collective memory; the celebrations did not stimulate a nationwide reflection on the achievements of the era commenced with the events of 1989 . They did not make a contribution to creating in the collective memory a 'national consensus of pride' at the regained statehood reminiscent of that of the Second Republic. 